\title{
STUDY OF THE DEVELOPMENT OF RURAL AREAS KULONPROGO DISTRICT (LOCATING A NEW GROWTH CENTER)
}

\author{
Luthfi Mutaali \\ Universitas Gadjah Mada \\ JI. Kaliurang, Sekip Utara, Bulaksumur Sinduadi Sleman, Daerah Istimewa Yogyakarta 55281 \\ E-mail corresponding: luthfimutaali@ugm.ac.id
}

\begin{tabular}{|c|c|c|}
\hline Submitted: & Accepted: & Published: \\
$19-12-2020$ & $20-01-2021$ & $31-01-2021$ \\
\hline
\end{tabular}

\begin{abstract}
This study aims to identify the dynamics of regional development and find a new growth centers in Kulonprogo Regency which are based on rural areas. By using a quantitative analysis of regional development indicators, the results showed that out of 88 villages in Kulonprogo Regency, $19.4 \%$ had high and very high potential for regional development, supported by the availability of facilities and infrastructure, and also a high and very high centrality value, around $21.6 \%$. These villages have the potential to be an embryo growth centers with potential criteria high (17\%) and very high (6.8\%). Chi Square test and Pearson correlation show a close relationship between the factors that form the center of growth, such as population density and growth, level of regional development, availability of infrastructure, and the value of centrality. Four main urban centers (PUP) were selected, namely the villages of Pengasih, Wates, Giripeni, and Bendungan. The Center for Alternative Growth (PPA), namely Brosot, Sentolo, Jati Srono, Gerbosari villages. The rest will support the Alternative Growth Center, Airport Area, Aerocity, and rural hinterlands.
\end{abstract}

Keywords: Regional development level, Growth center, Rural

\section{Introduction}

In an effort to analyze and plan development and regional growth, especially in rural areas, regional planners face problems of inequality, particularly in the production structure and infrastructure (Rondinelli, 1987). This imbalance can be identified as underdeveloped or poor areas, underdeveloped areas, or too developed areas. In terms of regional production, this inequality can also be differentiated into income inequality, job opportunities, basic needs service facilities, and so on (Muta'ali, 2012).

In the context of disparities or distortions, the urban-rural system illustrates the malfunctioning of the urban system hierarchy (Fishrer, 1983), resulting in an overconcentration of growth in certain cities (Kamal Sholeh, 1978). On the other hand, the development of other cities and villages is relatively backward. This illustrates that areas that are far from growth centers tend to be less developed than areas close to growth centers (Friedman, 1978). On a small scale, the above phenomenon is found in Kulon Progo district, Yogyakarta Province, where regional growth only occurs in the central government area (Regency Capital).

To reduce inequality in development, it is necessary to determine the location as the center of growth. The issue of location is a matter of selecting a suitable place in the sense that it can provide efficiency from certain activities, seen from the activity itself and from its relation to activities in other places. The purpose of determining the location of objects and places where activities take place or in this case as a growth center is intended to achieve efficiency and optimization. This growth center will function optimally if there are a certain number of residents who take advantage of the facility and can function efficiently if the growth center can be easily reached by residents. This growth center is expected to become a core area that functions to provide a positive effect of development on the surrounding areas which are hinterland areas (Fu Chen Lo, 1987). One of the regional development models that is closely related to the spatial aspect is the concept of growth centers which is based on two basic hypotheses, namely, (1) economic growth and development begins and reaches its peak at a certain number of centers, (2) economic 
growth and development is carried out from the center of growth, and nationally through urban and regional hierarchies from growth centers to the periphery or its influence. - each of which depends on market mechanisms and innovation (Hanafiah, 1987). Growth centers are used as an alternative strategy to reduce development disparities based on the role of growth centers in development in capturing innovations that bring growth down the urban hierarchy from spreading the existing profits from these growth centers to peripheries or hinterlands, especially in rural areas (Bastemeijer, T. et al. 1987). A growth center will encourage the emergence of business and employment opportunities, the creation of economies of scale, encourage innovation, create capital accumulation, the growth cycle, and the expansion of the concentration of economic activity so as to encourage economic activity from the areas it affects, and give rise to the concept of polarization which essentially creates economic agglomeration (Muta'ali, 2012). The hierarchical concept of growth centers will be more effective and efficient in terms of development efficiency and optimization than development is spread in the development area, especially the new center or location where it is developed will be expanded, this is very closely related to the existing conditions and basic capital in the region, and for the early stages of development this growth center concept would be more appropriate. Based on this, it can be understood that the growth center hierarchy is an efficient system in spreading regional development. In the last three years, Kulonprogo Regency Yogyakarta Province has experienced an extremely fast regional development phenomenon, triggered by the construction of YIA Airport (Yogyakarta International Airport) and plans to develop an aerotropolis city around the airport. Various problems as a result of these developments are uncontrolled land prices, employment opportunities, housing, socio-economic infrastructure, and a decline in environmental quality which are obstacles that must be watched out for.

Another problem is related to the characteristics of the city-city system, so the dynamics of the rapid development of the region allow for a concentration of development, especially along the YogyaWates-Temon corridor. This area will develop very quickly and enlarge to the periphery, thus forming a space that requires serious attention. Meanwhile, other areas, especially other rural areas, are relatively stagnant. This implies a regional growth gap phenomenon. The delay in development in areas outside the Kulonprogo development corridor is not caused by low regional potential and an accessibility system in spurring regional development, because economically there are sectors of economic activity that are quite prominent with adequate support for regional accessibility, but possibly more. the result is too large the dominance of the growth center which will take a large part of the regional growth function. On the other hand, if YIA and the aetropolis area cannot play their function as growth centers that are able to provide a trickle-down effect for regional development, this will be the beginning of failure in regional development.

The uneven pattern of regional development will result in regional development disparities, which can have a bad effect on the continuity of development, therefore an integrated and comprehensive handling effort is required (Ernan, 2011). This study examines in depth how to reduce these inequalities by analyzing the potential for growth centers into the framework of rural spatial planning, both functionally and territorially using the bottom-up approach, namely the application of the growth center strategy in rural areas.

\section{Methods}

The scope of this research area is the administrative area of Kulonprogo Regency, DIY Province. The analysis unit of this study was the 88 villages that spread across Kulon Progo Regency. The village was chosen as the unit of analysis because this research topics were regional development and determination of new growth centers that were based on rural areas. These rural areas have a variety geographic conditions and varying physical environments, which result in varied socioeconomy, environmental characteristics, and developmental developments. 
Table 1. Research Indicators and Variables

\begin{tabular}{|c|c|c|}
\hline No & Indicator & Variable \\
\hline 1 & $\begin{array}{l}\text { Regional Development } \\
\text { Level }\end{array}$ & $\begin{array}{l}\text { Using Indicator of Independent Village which includes: } \\
\text { 1. Social Capability Index } \\
\text { 2. Economic Resilience Index } \\
\text { 3. Environment Resilience Index } \\
\text { 4. Classification of Independent Village } \\
\text { The higher the value of social, economic, and environment resilience, the higher } \\
\text { level of regional development. }\end{array}$ \\
\hline 2 & $\begin{array}{l}\text { Potential Growth } \\
\text { Center (Village) }\end{array}$ & $\begin{array}{l}\text { 1. Demographics (Population Density and Growth) } \\
\text { 2. Availability of Facilities and Infrastructure (Schalogram Value) } \\
\text { 3. Geographical Position and Value of Centrality } \\
\text { 4. Development Expenditures } \\
\text { The higher the demographic index, the availability of facilities and infrastructure } \\
\text { for the village area and the value of centrality, the greater the potential for } \\
\text { becoming a new growth center }\end{array}$ \\
\hline
\end{tabular}

Source: Research analysis, 2020

In general, this research is a descriptiveanalytical study with a quantitative approach based on secondary data analysis which includes details of regional development variables and factors related to growth centers. These indicators were derived through literature review and operationally obtained from data sources such as the Independent Village Index (IDM) from the Ministry of Desa Tertinggal (2020), Kecamatan Dalam Angka (2020), and Village Potential Data (2018). Several indicators and research variables are presented in Table 1.

Data processing and analysis procedures: (Anonymous, 1983, Muta'ali, 2015)

1. A scoring analysis of the detailed variables (input) of social, economic, and environmental resilience to obtain an index value for regional development potential. Furthermore, the level of regional development is classified.

2. Quantitative descriptive analysis on demographic variables and the availability of facilities and infrastructure, including the calculation of the scalogram value and centrality.

3. Analysis of the relationship between potential determinants of growth centers

4. Analysis of the potential index of new growth centers by combining the regional development index values, demographic aspects, infrastructure, geographical position, and the value of centrality.

5. Spatial analysis, in the form of mapping all the thematic information that has been generated in the research, especially the selection of a new growth center in Kulonprogo Regency.

\section{Results and Discussions}

Among the 88 villages spread across 12 subdistricts in Kulon Progo Regency, Wates, Sentolo and Pengasih Districts are relatively prominent, both in terms of number, growth, and population density. Wates and Pengasih sub-districts are geographically bordered, forming Wates urban agglomeration as the district capital. If added together, 23.5 percent or nearly a quarter of the population of Kulon Progo Regency concentrates in these two subdistricts. Another potential demographic area is Sentolo District (11.65\%), which is in the development corridor of Yogya -Wates-Airport (See table 2).

The magnitude of the role of the three subdistricts can also be seen in the population growth data, where the villages in the district have a higher population growth than the population growth in Kulon Progo Regency of $1.38 \%$ / year. Temon District, the area where there is Yogyakarta International Airport, has experienced population growth in the same high school as Wates District, while in the southern part there is high population growth in Lendah District. From the aspect of population density, apart from Wates City, there are two areas with the second and third highest densities in the southern part, namely Galur and Lendah Districts. High population growth indicates the demographic potential to become new growth centers, while high density is generally an area that has been developing for a long time. 
Table 2. Population Characteristics and Density in Kulon Progo Regency

\begin{tabular}{|c|c|c|c|c|c|c|c|c|c|}
\hline & \multirow[t]{2}{*}{ Districts } & \multirow{2}{*}{$\begin{array}{c}\text { Number of } \\
\text { Villages }\end{array}$} & \multicolumn{3}{|c|}{ Area } & \multicolumn{2}{|c|}{ Population } & \multicolumn{2}{|c|}{$\begin{array}{c}\text { Density } \\
\text { Population }\end{array}$} \\
\hline & & & $(\mathrm{Ha})$ & $(\%)$ & Summary & (\%) & (\%/years) & Soul/Ha & Rank \\
\hline 1 & Temon & 15 & 3629 & 6,19 & 27310 & 6,41 & 1,51 & 8,52 & 7 \\
\hline 2 & Wates & 8 & 3200 & 5,46 & 49090 & 11,53 & 1,51 & 15,59 & 1 \\
\hline 3 & Panjatan & 11 & 4459 & 7,61 & 36955 & 8,68 & 1,36 & 9,01 & 6 \\
\hline 4 & Galur & 7 & 3291 & 5,61 & 31715 & 7,45 & 1,18 & 11,07 & 3 \\
\hline 5 & Lendah & 6 & 3559 & 6,07 & 40212 & 9,44 & 1,43 & 11,54 & 2 \\
\hline 6 & Sentolo & 8 & 5265 & 8,98 & 49589 & 11,65 & 1,44 & 9,80 & 4 \\
\hline 7 & Pengasih & 7 & 6166 & 10,52 & 50412 & 11,84 & 2,71 & 9,35 & 5 \\
\hline 8 & Kokap & 5 & 7380 & 12,59 & 32553 & 7,64 & 0,57 & 4,37 & 10 \\
\hline 9 & Girimulyo & 4 & 5490 & 9,37 & 23018 & 5,41 & 0,74 & 4,25 & 11 \\
\hline 10 & Nanggulan & 6 & 3961 & 6,76 & 30076 & 7,06 & 1,36 & 8,02 & 8 \\
\hline 11 & Kalibawang & 4 & 5296 & 9,03 & 28242 & 6,63 & 0,75 & 5,37 & 9 \\
\hline \multirow[t]{2}{*}{12} & Samigaluh & 7 & 6929 & 11,82 & 26649 & 6,26 & 1,08 & 3,87 & 12 \\
\hline & Jumlah & 88 & 58627 & 100 & 425821 & 100 & 1,38 & 8,84 & \\
\hline
\end{tabular}

The distribution of villages based on population classification and density in Kulon Progo district shows a similar incident. The main focus in the study of growth centers requires the need to pay attention to villages with high population growth and area density. The percentage of population growth in the high classification was dominated by Pengasih at $71 \%$, followed by Temon District at 33\%, and Wates District at 25\%. High class population density is in the Sentolo Cluster, which is traversed by the arterial route from Yogyakarta City and directly adjacent to Bantul Regency in the east. Some of the Sedayu Clusters, Galur Clusters, and Lendah Clusters are directly adjacent to Bantul Regency to the east. Part of the Pengasih Cluster and the Wates Cluster are the center of activity in Kulon Progo Regency and are traversed by an arterial road connected by Yogyakarta city.

Table 3. classification of density and population growth

\begin{tabular}{|c|c|c|c|c|c|c|c|c|}
\hline & \multirow[t]{2}{*}{ Districts } & \multirow{2}{*}{$\begin{array}{l}\text { Number of } \\
\text { Villages }\end{array}$} & \multicolumn{3}{|c|}{$\begin{array}{c}\text { Density Classification } \\
\text { Population (\%) }\end{array}$} & \multicolumn{3}{|c|}{$\begin{array}{c}\text { Classification } \\
\text { Population growth (\%) }\end{array}$} \\
\hline & & & $\mathrm{R}$ & $S$ & $\mathrm{~T}$ & $\mathrm{R}$ & $S$ & $\mathrm{~T}$ \\
\hline 1 & Temon & 15 & 53 & 33 & 13 & 33 & 33 & 33 \\
\hline 2 & Wates & 8 & 13 & 25 & 63 & 13 & 63 & 25 \\
\hline 3 & Panjatan & 11 & 27 & 64 & 9 & 27 & 73 & \\
\hline 4 & Galur & 7 & 14 & 43 & 43 & 14 & 86 & \\
\hline 5 & Lendah & 6 & & 67 & 33 & & 100 & \\
\hline 6 & Sentolo & 8 & 13 & 63 & 25 & & 100 & \\
\hline 7 & Pengasih & 7 & 43 & 29 & 29 & & 29 & 71 \\
\hline 8 & Kokap & 5 & 100 & & & 100 & & \\
\hline 9 & Girimulyo & 4 & 100 & & & 100 & & \\
\hline 10 & Nanggulan & 6 & 50 & 50 & & & 100 & \\
\hline 11 & Kalibawang & 4 & 100 & & & 100 & & \\
\hline \multirow[t]{2}{*}{12} & Samigaluh & 7 & 100 & & & & 100 & \\
\hline & Total & 88 & 45 & 35 & 19 & 26 & 60 & 14 \\
\hline
\end{tabular}

$\mathrm{R}=$ Low, $\mathrm{S}=$ Medium, and $\mathrm{T}=$ High

Some of the Panjatan Clusters and the Temon Clusters that are close to the Wates district (Table 3). Based on the demographic aspect, the village village clusters along the Yogyakarta-Wates-Teman (airport) corridor have a high population growth rate indicating 
the potential of the village to become a new growth center.

\section{Regional Development Level Factors}

The factor of regional development level in Kulon Progo Regency can be analyzed using two events, that are searching the index of regional development level, and knowing the distribution of the level of regional development (village) based on the classification of village development level. The index value of regional development level is derived from Decree of the Minister for Development of Underdeveloped Regions about Independent Village Index (IDM) Classification. Index and distribution table for regional development level was classified in Table 4.

Table 4. Regional Development Level Index in Kulon Progo Regency

\begin{tabular}{clcccccc}
\hline \multirow{2}{*}{ No } & \multirow{2}{*}{ Districts } & Number of & \multicolumn{5}{c}{ Regional Development Level } \\
\cline { 4 - 8 } & Villages & IKS & IKE & IKL & ITPW & Rank \\
\hline 1 & Temon & 15 & 0,7524 & 0,6300 & 0,6933 & 0,6921 & 9 \\
2 & Wates & 8 & 0,7796 & 0,6786 & 0,7714 & 0,7433 & 1 \\
3 & Panjatan & 11 & 0,7408 & 0,6183 & 0,6182 & 0,6591 & 12 \\
4 & Galur & 7 & 0,7884 & 0,6271 & 0,8000 & 0,7415 & 2 \\
5 & Lendah & 6 & 0,8257 & 0,5500 & 0,6778 & 0,6768 & 11 \\
6 & Sentolo & 8 & 0,8100 & 0,6854 & 0,5917 & 0,6955 & 8 \\
7 & Pengasih & 7 & 0,8138 & 0,6548 & 0,6952 & 0,7213 & 4 \\
8 & Kokap & 5 & 0,7851 & 0,7300 & 0,6000 & 0,7050 & 6 \\
9 & Girimulyo & 4 & 0,7500 & 0,6667 & 0,6500 & 0,6885 & 10 \\
10 & Nanggulan & 6 & 0,7958 & 0,6778 & 0,6778 & 0,7165 & 5 \\
11 & Kalibawang & 4 & 0,7857 & 0,8083 & 0,6000 & 0,7315 & 3 \\
12 & Samigaluh & 7 & 0,7815 & 0,6309 & 0,7048 & 0,7036 & 7 \\
& Total & 88 & 0,7800 & 0,6525 & 0,6780 & 0,7031 & \\
\hline
\end{tabular}

IKS = Social Performance Index, IKE = Economic Performance Index IKL = Environmental Performance Index. (source IDM, 2020 Ministry of PDT)

Table 4 illustrates the regional development level index, which is composed of three parts, namely the Social Performance Index (IKS), the Economic Performance Index (IKE), and the Environmental Performance Index (IKL). The villages with the highest level of regional development include Wates District in 1st place, Galur District in 2nd place, and Kalibawang District in 3rd place. Wates and Galur Districts have been developed for a long time, but the Kalibawang District which has a hilly topography, as rank 3, shows commencement of even development activities. Spatially, the regional development level shows an even distribution, in south (Galur), middle (Wates) and North (Nanggulan).

Villages with a high index of regional development are the capital for the emergence of growth centers that come from within (internally). The distribution of the regional development level based on village development level classification was described in Table 5.

Table 5. Distribution of Regional Development Level Based on Village Development Level Classification in Kulon Progo Regency

\begin{tabular}{|c|c|c|c|c|c|c|c|}
\hline \multirow{2}{*}{ No } & \multirow{2}{*}{ Districts } & \multirow{2}{*}{$\begin{array}{c}\text { Number of } \\
\text { Villages }\end{array}$} & \multicolumn{5}{|c|}{ Classification of Regional Development Level (\%) } \\
\hline & & & SR & $\mathrm{R}$ & $S$ & $\mathrm{~T}$ & ST \\
\hline 1 & Temon & 15 & 20,0 & 13,3 & 53,3 & 6,7 & 6,7 \\
\hline 2 & Wates & 8 & 12,5 & 12,5 & 37,5 & 12,5 & 25,0 \\
\hline 3 & Panjatan & 11 & 45,5 & 36,4 & 18,2 & & \\
\hline 4 & Galur & 7 & & & 71,4 & 14,3 & 14,3 \\
\hline 5 & Lendah & 6 & 16,7 & 33,3 & 50,0 & & \\
\hline 6 & Sentolo & 8 & & 37,5 & 50,0 & 12,5 & \\
\hline 7 & Pengasih & 7 & 28,6 & & 28,6 & 28,6 & 14,3 \\
\hline 8 & Kokap & 5 & & 20,0 & 60,0 & 20,0 & \\
\hline 9 & Girimulyo & 4 & & 25,0 & 75,0 & & \\
\hline 10 & Nanggulan & 6 & 16,7 & 16,7 & 33,3 & 16,7 & 16,7 \\
\hline 11 & Kalibawang & 4 & & & 75,0 & 25,0 & \\
\hline 12 & Samigaluh & 7 & 28,6 & 28,6 & 14,3 & 14,3 & 14,3 \\
\hline & Total & 88 & 17,0 & 19,3 & 44,3 & 11,4 & 8,0 \\
\hline
\end{tabular}


$\mathrm{SR}=$ Very Low, $\mathrm{R}=$ Low, $\mathrm{S}=$ Medium, $\mathrm{T}=$ High, $\mathrm{ST}=$ Very High

The level of regional development, especially rural villages, has a tendency high and very high in Kulon Progo district at $18.4 \%$, spread over four) districts covering Wates District, Galur District, Pengasih District, Nanggulan and Kalibawang District. Subdistrict of Wates, $12.5 \%$ is high and $25 \%$ is very high. Galur District of $14.3 \%$ respectively for high classification and very high classification. Pengasih sub-district amounted to $28.6 \%$ high classification and $14.3 \%$ very high classification. Kalibawang sub-district of $25 \quad 5 \%$ high classification. The villages in the four subdistricts have the potential to become new growth centers.

Analysis of the Map of Regional Development Potentials There are six sections with high potential for development. The first part of the Sentolo Cluster consists of Sentolo Village, Banguncipto Village, and other villages that are followed by arterial routes from Yogyakarta City which leads to Wates District. The second part of the Pengasih Cluster through which the collector route connects the artery route from the city of Yogyakarta makes accessibility easier. The third part of the Girimulyo Cluster, which consists of Kembang Village, Jatisarno Village, and other villages through which the collector's road from Sleman Regency passes. The fourth part of the Kalibawang Cluster is the collector route from Magelang Regency which consists of Banjaroyo Village, Banjarsari Village, and other villages through the collector route from Magelang Regency. The fifth part of the Galur Cluster consists of Brosot Village, Kranggan Village, and other villages through which the collector route from Bantul Regency passes. The sixth part of the Temon Cluster, which consists of villages around the Airport Area, which is traversed by the arterial road from Purworejo Regency. The following is a map of the potential for regional development in Kulon Progo Regency

\section{Centrality and Availability of Facilities and Infrastructure Factors}

The availability of facilities and infrastructure in Kulon Progo Regency can be analyzed using two methods, first by looking for the scalogram index, second by using centrality index.

The scalogram index describes the completeness of regional facilities and infrastructure, while the value of the centrality index shows centeredness, particularly the orientation of movement in using regional facilities and infrastructure. Villages that have a high index of facilities (schalogram) tend to have a high centrality value, so that they become a hierarchy of facilities and infrastructure centers. In more detail, results of the scalogram index and centrality index in Kulon Progo Regency was described in Table 6.

Pengasih District, Wates District, and Kalibawang District based on the schalogram index were ranked 1st, 2nd, and 3rd respectively. This shows that the complete availability of facilities and infrastructure is dominated in Pengasih, Wates, and Kalibawang Districts. The positions of the Wates and Pengasih Districts have changed places on the aspect of centrality, so that these three districts are the center of orientation for the movement of the population of Kulon Progo Regency in utilizing the regional facilities and infrastructure. Wates and Pengasih sub-districts in the middle (bottom) which are plains and Kalibawang subdistricts in the north (above) are the centers of both economic and social activities.

Table 6. Schalogram Index and Regional Centrality in Kulon Progo Regency

\begin{tabular}{clccccc}
\hline \multirow{2}{*}{ No Districts } & Number of & \multicolumn{4}{c}{ Schalogram and Centrality } \\
\cline { 3 - 6 } & & Villages & Schalogram Index & Rank & Centrality Index & Rank \\
\hline 1 & Temon & 15 & 32,43 & 12 & 28,10 & 12 \\
2 & Wates & 8 & 50,17 & 2 & 53,15 & 1 \\
3 & Panjatan & 11 & 34,27 & 11 & 29,08 & 11 \\
4 & Galur & 7 & 41,31 & 6 & 40,61 & 5 \\
5 & Lendah & 6 & 41,67 & 5 & 38,78 & 7 \\
6 & Sentolo & 8 & 42,74 & 4 & 41,06 & 4 \\
7 & Pengasih & 7 & 51,16 & 1 & 51,62 & 2 \\
8 & Kokap & 5 & 38,38 & 9 & 37,53 & 8 \\
9 & Girimulyo & 4 & 39,19 & 8 & 36,40 & 9 \\
10 & Nanggulan & 6 & 40,32 & 7 & 39,77 & 6 \\
11 & Kalibawang & 4 & 49,66 & 3 & 50,14 & 3 \\
12 & Samigaluh & 7 & 37,45 & 10 & 34,63 & 10
\end{tabular}


Total 88

40,40

38,50

Based on the Schalogram and Centrality Index Classification in Kulon Progo Regency, it was found that $21 \%$ of villages in Kulon Progo Regency had high and very high schalogram values and centrality, so that they had the opportunity to become growth centers (Table 7).

Based on the analysis of the distribution map of the schalogram value and the centrality of 88 villages in Kulon Progo district, it can be seen that there are several high hierarchical clusters, namely the Wates and Pengasih Clusters, Sentolo Clusters, Kalibawang Clusters and Galur-Lendah Clusters. This high cluster is located in the corridor of arterial roads and collector roads originating from Yogyakarta City such as the Sentolo Cluster which is located in the southern route and is the only area with the strongest and potential character. Despite its position in a rural area, however, this cluster has a high regional hierarchy and strong urban characteristics. Srangkan-Galur is located on the southern coast of Yogyakarta Province and is a transportation hub in the southern route. In spatial planning, these two areas are designated for agriculture, tourism, settlement, and trade areas. This cluster is relatively independent and far from the influence of the development of the city of Yogyakarta and its surroundings. The plan to develop the southern Java route, especially starting from Cilacap-Pacitan, provides potential future opportunities for this cluster to become a new growth center, particularly in the southern route.

Table 7. Village Distribution Based on the Schalogram Index Classification and Centrality in Kulon Progo Regency

\begin{tabular}{|c|c|c|c|c|c|c|c|c|}
\hline \multirow[b]{2}{*}{ No } & \multirow[b]{2}{*}{ Districts } & \multirow[b]{2}{*}{$\begin{array}{c}\text { Number of } \\
\text { Villages }\end{array}$} & \multicolumn{3}{|c|}{ Schalogram } & \multicolumn{3}{|c|}{ Centrality } \\
\hline & & & $\begin{array}{c}S R \text { and } \\
R\end{array}$ & $S$ & $\begin{array}{c}\mathrm{T} \\
\text { and } \mathrm{ST}\end{array}$ & $\begin{array}{c}S R \\
\text { and } R\end{array}$ & $S$ & $\begin{array}{c}\mathrm{T} \\
\text { and } S T\end{array}$ \\
\hline 1 & Temon & 15 & 66,7 & 33,3 & & 86,7 & 13,3 & \\
\hline 2 & Wates & 8 & 37,5 & 12,5 & 50,0 & 37,5 & 12,5 & 50,0 \\
\hline 3 & Panjatan & 11 & 54,5 & 45,5 & & 72,7 & 27,3 & \\
\hline 4 & Galur & 7 & 42,9 & 28,6 & 28,6 & 42,9 & 28,6 & 28,6 \\
\hline 5 & Lendah & 6 & 16,7 & 66,7 & 16,7 & 50,0 & 33,3 & 16,7 \\
\hline 6 & Sentolo & 8 & 12,5 & 75,0 & 12,5 & 37,5 & 37,5 & 25,0 \\
\hline 7 & Pengasih & 7 & 0,0 & 42,9 & 57,1 & 14,3 & 42,9 & 42,9 \\
\hline 8 & Kokap & 5 & 60,0 & 20,0 & 20,0 & 60,0 & 20,0 & 20,0 \\
\hline 9 & Girimulyo & 4 & 50,0 & 25,0 & 25,0 & 50,0 & 25,0 & 25,0 \\
\hline 10 & Nanggulan & 6 & 50,0 & 33,3 & 16,7 & 50,0 & 33,3 & 16,7 \\
\hline 11 & Kalibawang & 4 & 0,0 & 25,0 & 75,0 & 25,0 & & 75,0 \\
\hline 12 & Samigaluh & 7 & 42,9 & 42,9 & 14,3 & 57,1 & 28,6 & 14,3 \\
\hline & Jumlah & 88 & 39,8 & 38,6 & 21,6 & 53,4 & 25,0 & 21,6 \\
\hline
\end{tabular}

$\mathrm{SR}=$ Very Low, $\mathrm{R}=$ Low, $\mathrm{S}=$ Medium, $\mathrm{T}=$ High, $\mathrm{ST}=$ Very High

\section{Growth Center Potential Index}

The potential growth center index is used to describe which districts have the potential to become new growth centers in Kulon Progo Regency. The growth center potential index is a composite index (combined) of demographic factors, regional development factors and factors or the scalogram value and centrality index. The higher the potential growth center index value, the greater the opportunity to be developed as a growth center.

Table 8. Village Distribution Based on Value Classification of Potential Growth Centers (PPP) in Kulon Progo Regency

\begin{tabular}{|c|c|c|c|c|c|c|c|c|}
\hline \multirow{2}{*}{ No } & \multirow{2}{*}{ Districts } & \multirow{2}{*}{$\begin{array}{c}\text { Number of } \\
\text { Villages }\end{array}$} & \multicolumn{6}{|c|}{ Potensi Pusat Pertumbuhan (PPP) } \\
\hline & & & Indek PPP & SR & $\mathrm{R}$ & $S$ & $\mathrm{~T}$ & ST \\
\hline 1 & Temon & 15 & 9,87 & 26,7 & 40,0 & 26,7 & 6,7 & \\
\hline 2 & Wates & 8 & 14,13 & & 25,0 & 25,0 & 25,0 & 25,0 \\
\hline 3 & Panjatan & 11 & 9,27 & 36,4 & 45,5 & 9,1 & 9,1 & \\
\hline 4 & Galur & 7 & 13,29 & & 28,6 & 28,6 & 28,6 & 14,3 \\
\hline 5 & Lendah & 6 & 12,33 & & 16,7 & 66,7 & 16,7 & \\
\hline 6 & Sentolo & 8 & 12,88 & & 25,0 & 50,0 & 12,5 & 12,5 \\
\hline 7 & Pengasih & 7 & 14,71 & & 14,3 & 14,3 & 57,1 & 14,3 \\
\hline 8 & Kokap & 5 & 9,80 & 40,0 & 20,0 & 40,0 & & \\
\hline 9 & Girimulyo & 4 & 10,25 & 25,0 & 25,0 & 50,0 & & \\
\hline 10 & Nanggulan & 6 & 11,67 & 33,3 & 16,7 & 16,7 & 16,7 & 16,7 \\
\hline 11 & Kalibawang & 4 & 12,50 & & 25,0 & 50,0 & 25,0 & \\
\hline \multirow[t]{2}{*}{12} & Samigaluh & 7 & 10,29 & 42,9 & 28,6 & 14,3 & 14,3 & \\
\hline & Total & 88 & 11,57 & 18,2 & 28,4 & 29,5 & 17,0 & 6,8 \\
\hline
\end{tabular}


$S R=$ Very Low, $R=$ Low,$S=$ Medium, $T=$ High, $S T=$ Very High

Table 8 illustrates the classification of potential growth centers per district in Kulon Progo Regency. There are four districts with high potential for growth centers including Wates, Galur, Sentolo, and Pengasih Districts. Of the four sub-districts with the highest growth potential, Pengasih was the most dominating with the highest growth center potential index of 14.71 and the highest growth center potential classification of $57.1 \%$ high classification and $14.3 \%$ very high classification. Map of the potential growth centers in Kulon Progo Regency was showed in Figure 1.

Map of Potential Growth Centers can be divided into four pathways which are closely related to accessibility to service centers and community activity centers. The first route is an arterial road that connects Yogyakarta

City with Wates District so that the impact on the Sentolo Cluster has the potential as a growth center. The second route is the collector road that connects Bantul Regency with Kulon Progo Regency so that the impact on the Low Cluster and the Line Cluster which has the potential to become a growth center. The Sedayu cluster is between the first line and the second line, so it has the potential to become a growth center. The fourth route is the arterial line that connects Purworejo Regency with Wates District, as well as the City of Yogyakarta, thereby increasing activity in the Temon Cluster which has an impact on the increase in land value that has the potential to become a growth center.

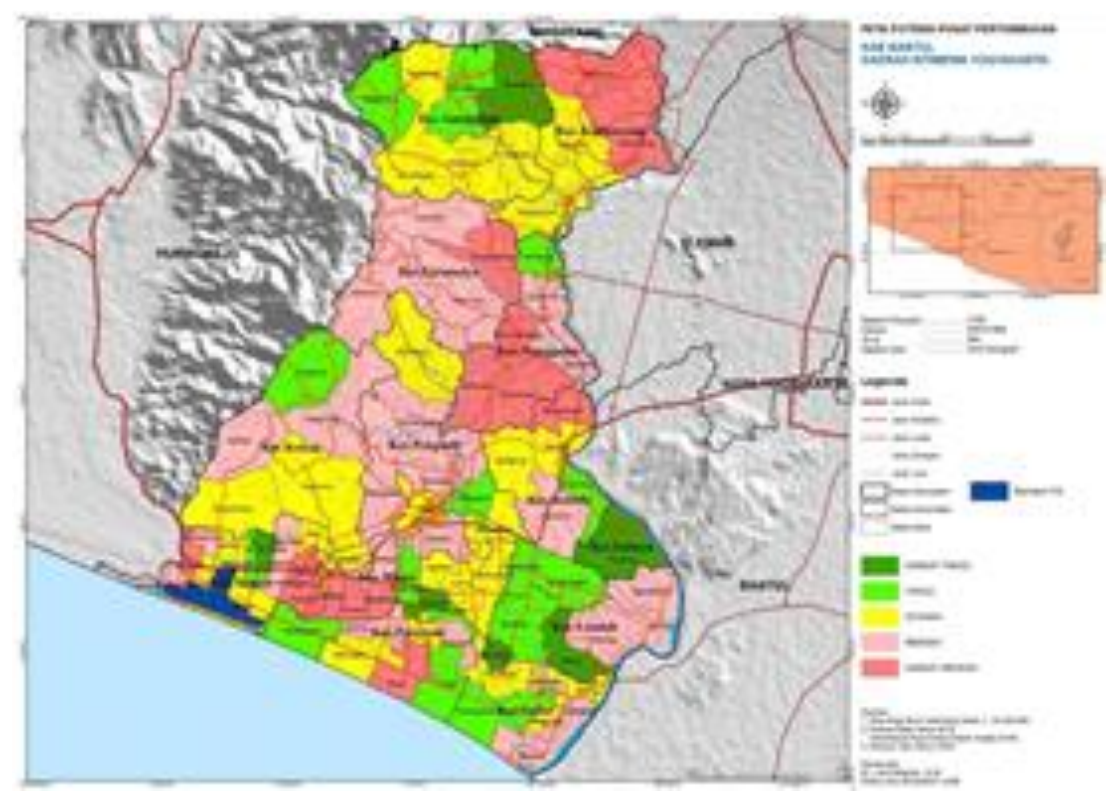

Figure 1. Map of the Potential Growth Center of Kulon Progo Regency

\section{Relation of Regional Indicators and Potential Growth Centers}

It is necessary to know the relationship between potential growth centers and regional indicators in order to establish continuity with new growth centers for regional conditions.
The relationship between potential growth centers and regional indicators can be determined using the Pearson Chi Square Test. In more detail, the relationship between potential growth centers and regional indicators is shown in Table 9.

Table 9. Pearson Chi Square Test Correlation of Potential Growth Centers with Regional Indicators

\begin{tabular}{lccc}
\hline \multicolumn{1}{c}{ Regional Indicators } & Value & $\mathrm{df}$ & $\begin{array}{c}\text { Asymp. Sig. } \\
(2 \text {-sided) }\end{array}$ \\
\hline Population growth & $15.691^{\mathrm{a}}$ & 8 &, 047 \\
Population density & $27.678^{\mathrm{a}}$ & 8 &, 001 \\
Level of Development & $64.071^{\mathrm{a}}$ & 16 &, 000 \\
Territory & $166.344^{\mathrm{a}}$ & 16 &, 000 \\
Schalogram Index & $145.880^{\mathrm{a}}$ & 16 &, 000 \\
Centrality Index & $91.345^{\mathrm{a}}$ & 20 &, 000 \\
\hline
\end{tabular}


Source: Analysis Data, 2020

Table 10. Correlation Test among Regional Indicators

\begin{tabular}{|c|c|c|c|c|c|c|c|}
\hline & & $\mathrm{X} 1$ & $\mathrm{x} 2$ & X3 & $\mathrm{X} 4$ & $\mathrm{X} 5$ & $\mathrm{X} 6$ \\
\hline \multirow{2}{*}{$\mathrm{X} 1$} & Pearson Correlation & 1 & ,207 & , 122 & $.256^{*}$ & $.243^{*}$ & $.385^{* * *}$ \\
\hline & Sig. (2-tailed) & & ,053 & ,257 & ,016 & ,023 & ,000 \\
\hline \multirow{2}{*}{$\times 2$} & Pearson Correlation & ,207 & 1 & $.376^{* *}$ & $.516^{* * *}$ & $.559^{* * *}$ & $.533^{* *}$ \\
\hline & Sig. (2-tailed) & ,053 & & ,000 & , 000 &, 000 & ,000 \\
\hline \multirow{2}{*}{$x 3$} & Pearson Correlation & ,122 & $.376^{* * *}$ & 1 & $.647^{* * *}$ & $.665^{* * *}$ & $.714^{* * *}$ \\
\hline & Sig. (2-tailed) & ,257 &, 000 & &, 000 &, 000 &, 000 \\
\hline $\mathrm{X} 4$ & $\begin{array}{l}\text { Pearson Correlation } \\
\text { Sig. (2-tailed) }\end{array}$ & $\begin{array}{l}.256^{*} \\
.016\end{array}$ & $\begin{array}{l}.516^{* * *} \\
.000\end{array}$ & $\begin{array}{l}.647^{* * *} \\
.000\end{array}$ & 1 & $\begin{array}{l}.960^{* * *} \\
.000\end{array}$ & $\begin{array}{l}.904^{* * *} \\
.000\end{array}$ \\
\hline$\times 5$ & $\begin{array}{l}\text { Pearson Correlation } \\
\text { Sig. (2-tailed) }\end{array}$ & $\begin{array}{l}.243^{*} \\
.023\end{array}$ & $\begin{array}{l}.559^{* * *} \\
.000\end{array}$ & $\begin{array}{l}.665^{* * *} \\
.000\end{array}$ & $\begin{array}{l}.960 * * \\
.000\end{array}$ & 1 & $\begin{array}{l}.853^{* * *} \\
.000\end{array}$ \\
\hline$\times 5$ & $\begin{array}{l}\text { Pearson Correlation } \\
\text { Sig. (2-tailed) }\end{array}$ & $\begin{array}{l}.385^{* *} \\
.000\end{array}$ & $\begin{array}{l}.533^{* * *} \\
.000\end{array}$ & $\begin{array}{l}.714^{* * *} \\
.000\end{array}$ & $\begin{array}{l}.904^{* * *} \\
.000\end{array}$ & $\begin{array}{l}.853^{* * *} \\
.000\end{array}$ & 1 \\
\hline
\end{tabular}

X1 = Population Growth, X2 = Population Density, X3 = Regional Development Level, X4 = Schalogram Index, X5 = Centrality Index, X6 = Regional Growth Center Potential Index

Table 9 illustrates the relationship between potential growth centers and regional indicators. In general, all regional indicators consisting of population growth, population density, level of regional development, the scalogram index, centrality index, and direction of the growth center have a positive

relationship to the potential of the growth center. This can be seen in the significance of the relationship below 0.05 or there is a relationship, and the value of the column value is all positive, which indicates that the relationship occurs positively.

Apart from looking for the relationship between regional indicators and potential growth centers, it is also necessary to look for the relationship between regional indicators and regional indicators so that it can be seen which indicators are interrelated and which indicators are not.

The relationship between regional indicators and regional indicators are shown in Table 10. Population growth indicator (X1) has a positive relationship with the indicators of the scalogram index, centrality index, and regional growth center potential index because the significance value is less than 0.05 . The population density indicator $(\mathrm{X} 2)$ has a positive relationship with the regional development level indicator, the analogue index indicator, the centrality index, and the regional growth center potential index because the significance value is less than 0.05 . The regional development level indicator $(X 3)$ has a positive relationship with the population density indicator, the scalogram index, the centrality index, and the regional growth center potential index because the significance value is less than 0.05 . The scalogram index indicator $(X 4)$ has a positive relationship with the population growth indicator, population density, centrality index, and regional growth center potential index because the significance value is less than 0.05 . The centrality index indicator $(X 5)$ has a positive relationship with the population growth indicator, population density, the scalogram index, and the regional growth center potential index because the significance value is less than 0.05 . The regional growth center potential index indicator (X6) has a positive relationship with the population growth indicator, population density, the scalogram index, and the centrality index because the significance value is less than 0.05 .

\section{Potential Growth Center and Growth Center Direction}

Based on the study of the potential for growth centers and constellation of regional development in Kulon Progo Regency, a direction for the growth center is made, which consists of 6 areas including the Main Urban Center, Alternative Growth Center, Alternative Growth Center Support Area, Airport Area, Aerocity (New Growth Center), and Hinterland of rural areas. Each new growth Zone has the potential as a growth center which is different in the potential growth center classes ranging from low to very high. More details are shown in Table 11 as follows. 
Table 11 Growth Centers and Direction of Growth Centers

\begin{tabular}{|c|c|c|c|c|c|c|c|c|}
\hline \multirow{2}{*}{ Growth Center Directive } & \multirow{2}{*}{ Villages } & \multicolumn{5}{|c|}{$\begin{array}{c}\text { Classification of Growth } \\
\text { Center Potential (\%) }\end{array}$} & \multirow[b]{2}{*}{$\Sigma$} & \multirow[b]{2}{*}{ (\%) } \\
\hline & & $S R$ & $\mathrm{R}$ & $S$ & $\mathrm{~T}$ & $S T$ & & \\
\hline Main Urban Center & Pengasih, Wates, Bendungan & 0 & 0 & 0 & 1 & 3 & 4 & 6,90 \\
\hline Center for Alternative Growth & $\begin{array}{l}\text { Brosot, Sentolo, Jati Srono, } \\
\text { Gerbosari }\end{array}$ & 0 & 0 & 0 & 1 & 3 & 4 & 6,90 \\
\hline $\begin{array}{l}\text { Supporters of Alternative } \\
\text { Growth Centers }\end{array}$ & $\begin{array}{l}\text { Karangsewu, Tirta Rahayu, } \\
\text { Banguncipto, Margosari, Kembang, } \\
\text { Banjararum }\end{array}$ & 0 & 0 & 1 & 5 & 0 & 6 & 10,34 \\
\hline Airport area & Sindutan, Palihan, Glagah & 0 & 2 & 1 & 0 & 0 & 3 & 5,17 \\
\hline $\begin{array}{l}\text { Aerocity (New Growth } \\
\text { Center) }\end{array}$ & $\begin{array}{l}\text { Kalidengen, Plumbon, Kedundang, } \\
\text { Demen, Kulur, } \\
\text { Kaligintung, Temon Wetan, Temon } \\
\text { Kulon, Kebonrejo, Janten, } \\
\text { karangwuluh, Karangwuni }\end{array}$ & 4 & 4 & 4 & 1 & 0 & 13 & 22,41 \\
\hline Rural hinterland & Villages outside 1-5 & 12 & 19 & 20 & 7 & 0 & 58 & 6,90 \\
\hline Total & & 18,2 & 28,4 & 29,5 & 17,0 & 6,8 & 88 & \\
\hline
\end{tabular}

$S R=$ Very Low, $R=$ Low,$S=$ Medium, $T=$ High, $S T=$ Very High

Potential growth centers as Main Urban Centers include Pengasih Village, Wates Village, and Dam Village. In general, the growth center potential class for Urban Main Centers tends to be high to very high with a percentage of $6.9 \%$. Potential growth centers as Alternative Growth Centers include Brosot Village, Sentolo Village, Jati Village, Srono Village, and Gerbosari Village. In general, the growth center potential class for Alternative Growth Centers tends to be high to very high with a percentage of $6.9 \%$. The potential of the growth center as a Support for the Alternative Growth Center covers six villages namely Karangsewu, Tirta Rahayu, Banguncipto, Margosari, Kembang, Banjararum. In general, the growth center potential class for Alternative Growth Center Supporters tends to be high to very high with a percentage of $10.34 \%$.

Potential growth centers as Airport Areas include Palihan Village, Sindutan Village, and Glagah Village. In general, the class of potential growth centers for Urban Main Centers tends to be low to moderate with a percentage of
$5.17 \%$. The potential growth centers as Aerocity (New Growth Centers) include thirteen (13) villages including Kalidengen, Plumbon, Kedundang, Demen, Kulur, Kaligintung, Temon Wetan, Temon Kulon, Kebonrejo, Janten, Karangwuluh, and Karangwuni. In general, the growth center potential class for Aerocity (New Growth Center) tends to be low to very low with a percentage of $22.41 \%$. The potential growth center as a Rural Hinterland includes 58 villages which are villages outside the village that are directed as urban Main Centers, Alternative Growth Centers, Supporting Alternative Growth Centers, Airport Areas, and Aerocity (New Growth Centers). In general, the growth center potential class for Hinterland Rural tends to be low to moderate with a percentage of $6.9 \%$. Spatially, the distribution of directions for the new growth centers in Kulon Progo district is shown in Figure 2. 


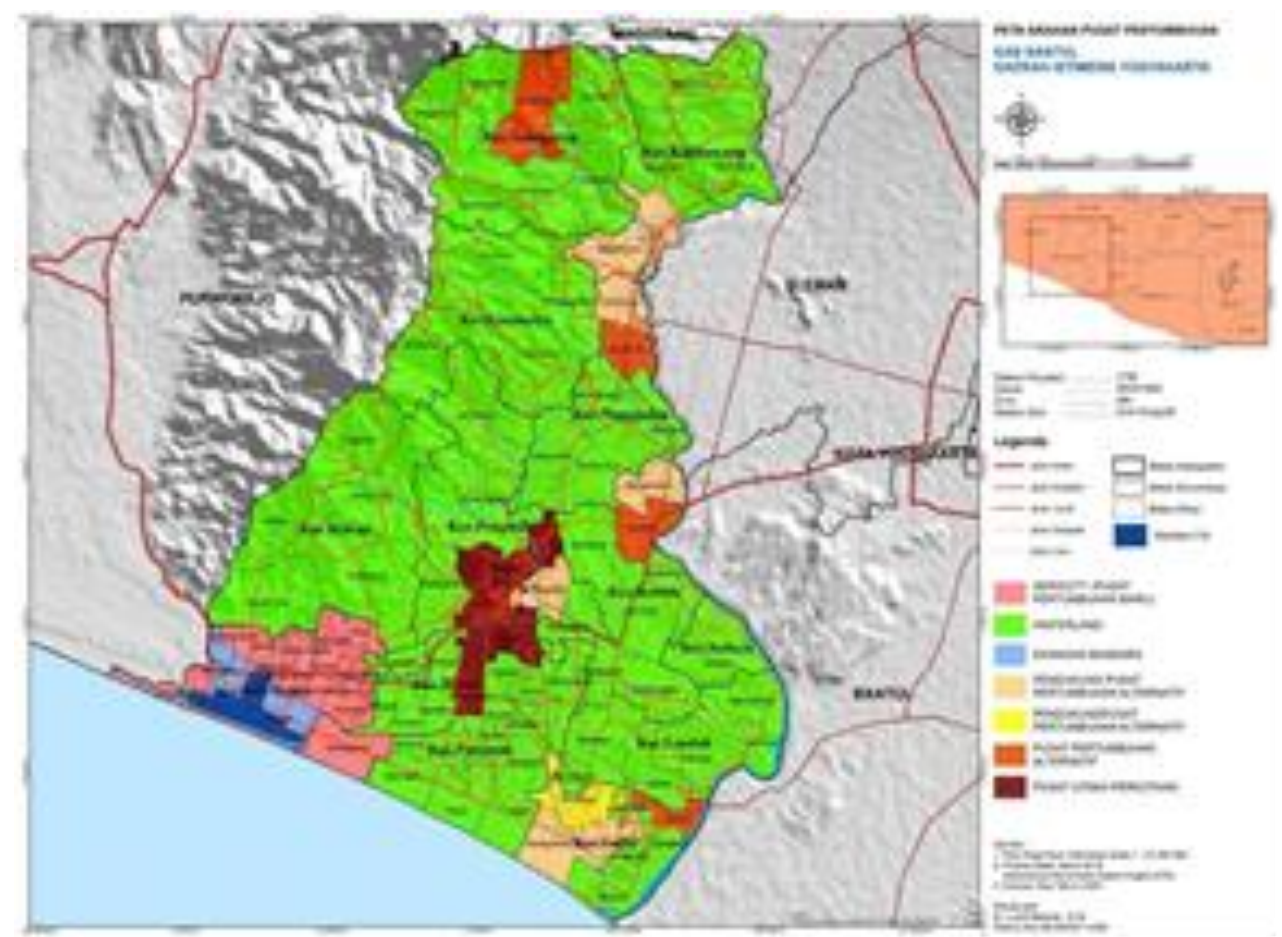

Figure 2. Map of Rural-Based New Growth Centers Directive in Kulon Progo Regency

\section{Conclusion}

The Study on Rural Areas of Development in Kulonprogo Regency in an effort to find a New Growth Center, concluded:

1. The level of development of rural areas in Kulonprogo Regency which is classified as high to very high reaches $19.4 \%$ or seventeen villages. The village has the potential to become the center of rural growth.

2. Potential analysis of rural growth centers found $23 \%$ or twenty villages have the potential to become growth centers with a fairly even spatial distribution, but four Main Urban Centers (PUPs) were selected, namely the villages of Pengasih, Wates, Giripeni, Dam and Alternative Growth Centers (PPA), namely Brosot village, Sentolo, Jati Srono, Gerbosari.

3. The potential for rural growth centers is determined by population growth, level of regional development, availability of infrastructure and the value of geographic centrality. The higher the indicator value, the higher it becomes the center of growth.

\section{Acknowledgment}

Thank you to the Department of Development Geography, Faculty of Geography, Gadjah Mada University, because for the opportunity, this research could be completed.

\section{References}

Anonim, 1983. Guidelines for Rural Center Planning, Economic and Social Commission for Asia and The Pasific. United Nation. New York.

Badan Pusat Statistik. 2018. Potensi Desa Kabupaten Kulon Progo. BPS. Jakarta

Badan Pusat Statistik. 2020. Kabupaten Kulon Progo Dalam Angka Tahun 2018-2020. BPS. Kulon Progo

Badan Pusat Statistik. 2020. Kecamatan Dalam Angka, Kabupaten Kulon Progo Tahun 2020. BPS. Kulon Progo

Bastemeijer, T. et al. 1987. An Approach to Rural Center Planning in the Framework of Integrated Regional Development. Depertement of Civil Engineering, University of Technology, Delf. The Netherlands

Dirjen Pembangunan dan Pemberdayaan Masyarakat Desa. 2020. Keputusan Dirjen Pembangunan dan Pemberdayaan Masyarakat Desa Nomor 303 Tahun 2020 Tentang Perubahan Ketiga Atas Keputusan Dirjen Pembangunan dan Pemberdayaan Masyarakat Desa Nomor 30 tahun 2016 Tentang Status Kemajuan dan Kemandirian Desa 
Ernan Rustiadi, Sunsun Saefulhakim dan Dyah R. Panuju. 2011. Perencanaan dan Pembangunan Wilayah. Jakarta: Yayasan Pustaka Obor Indonesia.

Fisher, H. B. dan Shyamadas. 1983. Hierarchical Location Analysis for Integrated Area Planning : Experience of the pilot Research Project in Growth Centers, India. Paper presented in the 1983 Regional Science Congress in Vienna.

Friedman, John. and Douglas, Mike, 1978, Agropolitan Development, Towards a new Strategy for Regional Planning in Asia, in Fu Chen Lo and Kamal Solih (ed). Growth Pole Strategy and Regional Development Policy, Asian Experience and Alternative Approaches, Pergamon Press, Oxford, England.

Fu Chen Lo dan Kamal Solih, 1976. Kutubkutub Pertumbuhan dan Kebijaksanaan Regional dalam Sistem Ekonomi Dualistik yang terbuka Teori Barat dan Kenyataan di Asia. Lembaga Penerbit FE - UI.

Hanafiah, T. 1987. Pengembangan Pusat Pertumbuhan dan Pelayanan Kecil Dalam Rangka Pengembangan Wilayah Perdesaan. Jurusan Ilmu-ilmu Sosial Ekonomi Pertanian, Fakultas Pertanian IPB, Bogor

Kamal Solih, et al. 1978. Decentralization Policy, Growth Pole Approach, and Resource Frontier Development. A Synthesis of the response in fourth Southeast Asian Countries, in Fu Chen Lo and Kamal Solih (ed), Growth Pole Strategy and Regional Development Policy, Asian Experience and Alternative Approaches. Pergamon Press, Oxford, England.

Muta'ali, Luthfi. 2012. Kapita Selekta Pengembangan Wilayah. Yogyakarta: Badan Penerbit Fakultas Geografi UGM.

Muta'ali, Luthfi. 2015. Teknik Analisis Regional, untuk Perencanaan Wilayah, Tata Ruang, dan Pengelolaan Lingkungan. Yogyakarta: Badan Penerbit Fakultas Geografi UGM.

Rondinelli, Dennis A. and Kenneth Ruddle. 1987. Urbanization and Rural Development: Spatial Policy for Equitable Growth., Preager Publisher. New York. 1978 